\title{
Sykepleiere trenger kollegastøtte når \\ uønskede hendelser \\ skjer (3:3)
}

Tilliten fra befolkningen $\varnothing$ delegges ikke av at vi gjør feil, men av at vi som helsepersonell ikke er åpne om uønskede hendelser.

\section{Elin Sagbakken}

Sykepleier og medlem av Rådet for sykepleieetikk

Kirkenes sykehus, Finnmarkssykehuset

\begin{tabular}{lll} 
Etikk Kollegastøtte $\quad$ Uheldige hendelser \\
\hline
\end{tabular}

Sykepleien 2021109 (86855) (e-86855)

DOI: 10.4220/Sykepleiens.2021.86855

\section{Hovedbudskap}

La oss være der for kollegaene våre - slik vi er der for pasientene og de pårørende. «Hva er viktig for deg?» spør vi pasientene om. Det samme spørsmålet må vi også stille til kollegaene våre når vi er kjent med at det har oppstått en uønsket hendelse. Artikkelen er den siste av tre artikler som handler om kollegastøtte.

Det er mange måter å bidra med kollegastøtte på, og flere avdelinger og organisasjoner har funnet sine rutiner for dette. Det finnes en rekke både formelle og uformelle måter å gjøre det på. 
I farta på vei til noe annet får jeg kanskje et klapp på skulderen av kollegaen min som sier: «Det kunne like gjerne vært meg». Det gir som oftest en kortvarig trøst, en slags «moralsk anestesi», og det er ikke alltid godt nok. Vi tar det kanskje for gitt at alle har noen å snakke med utenom jobb, men det er nok ikke slik for alle.

\section{«For å sikre god pasientsikkerhet er det viktig å gjøre en grundig gjennomgang av hendelsen.»}

For å sikre god pasientsikkerhet er det viktig å gjøre en grundig gjennomgang av hendelsen. Hva var det som skjedde, og hvorfor? Hvem hadde ansvaret? Hva kan vi lære av hendelsen, og hvordan kan vi forebygge at det skjer igjen?

Ikke minst må de involverte og deres ledere forstå handlingsalternativene man faktisk hadde på det tidspunktet da hendelsen inntraff. Vi kan fort gå i fellen og diskutere hendelsen ut fra kunnskapen vi innehar $i$ etterkant av hendelsen. Det er noe vi ofte erfarer ved saksgjennomgang internt $\mathrm{i}$ organisasjonen og eksternt av tilsynsmyndighetene.

Når man går gjennom en hendelse, er det viktig å snakke om ansvarsbegrepet. Dette begrepet betyr ikke nødvendigvis at den involverte sykepleieren kan klandres for den uønskede hendelsen. Det å ha ansvaret når noe går galt, er altså ikke ensbetydende med å ha skylden (2).

LES: Sykepleiere trenger kollegastøtte når uønskede hendelser skjer (1:3)

LES: Sykepleiere trenger kollegast øtte når uønskede hendelser skjer (2:3)

\section{Hendelsen må ikke feies under teppet}


Som nevnt tidligere trenger vi hjelp til å sortere de ulike begrepene som ansvar, skyld, skyldfølelse og skam. Dette er en jobb for lederen og kollegiet, ikke for sykepleieren alene. Men det er viktig at sykepleieren er åpen og ikke feier hendelsen under teppet.

\section{«Det er viktig at sykepleieren er åpen og ikke feier hendelsen under teppet.»}

Om sykepleieren ikke tilbys en systematisk

gjennomgang av og støtte rundt hendelsen, er det viktig å be om det, for det er ikke gitt at man får det. Her bør vi være oppmerksom på at den som har gjort en feil, kanskje ikke har det overskuddet som trengs til å be om hjelp.

I denne prosessen bør lederen være synlig, vise at feil og uønskede hendelser tilhører avdelingen og profesjonen, og vise at avdelingen har eierskap til en kultur bestående av bærekraft og mestring. Det er et lederansvar å sørge for at hendelsen ikke forblir taus, slik at skammen får grobunn (2).

\section{Verktøy for empatisk kommunikasjon kan være til hjelp}

Etter et oppklaringsmøte, der de involverte, avdelingslederen og ansvarshavende lege kritisk går gjennom hendelsen, har jeg har stor tro på en systematisk oppfølging med samtaler i kollegiet og mellom lederen (eventuelt en kollega med noe pedagogisk kompetanse) og den ansatte.

Det kan nok diskuteres om denne oppfølgingen skal være obligatorisk eller et tilbud. Personlig mener jeg den bør være obligatorisk - man kan sammenlikne det med ulike steg som $i$ et pasientforløp.

Det pedagogiske verkt øyet «Empatisk kommunikasjon» (4) kan være et godt verktøy å benytte i en slik situasjon. Samtalen vil avdekke om noen trenger «noe mer» i den videre oppfølgingen. 
Verktøyet består av fire trinn mellom «deltakeren» og «hjelperen»:

- Trinn 1: Den ansatte forteller sin historie (narrativ).

- Trinn 2: Den ansatte beskriver de følelsene som melder seg i forbindelse med den historien som er blitt fortalt (affektbevissthet: integrering og regulering av følelser).

- Trinn 3: Den ansatte setter ord på tanker og refleksjoner i forbindelse med sin egen historie og sine egne følelser (reflekterende funksjon).

- Trinn 4: Lederen eller kollegaen spør den ansatte om vedkommende vil høre lederens tanker og refleksjoner om det som er kommet frem i trinn 13. «Hjelperen» tilbyr seg å være medforteller.

De tre første trinnene i dialogen er et samspill og en prosess mellom den ansatte og lederen eller kollegaen, der den ansatte er hovedpersonen og den som har ordet.

For å tilrettelegge for den ansattes muligheter til å skape en indre dialog og ta i bruk evnen til selvrefleksjon bør samspillsprosessen foregå uten avbrytelser, kommentarer eller korreksjoner fra hjelperens side i de tre første trinnene i dialogen. I det siste trinnet er hjelperen en aktiv medforteller og samskaper av nye virkeligheter ut fra det som har kommet frem i den ansattes fortelling om seg selv, sine følelser og sine tanker.

Grunnlaget for verktøyet er kunnskap om menneskets medfødte evne til empati og selvrefleksjon samt vårt medfødte behov for kontakt. Ny kunnskap innen hjerneforskning og oppdagelsen av speilnevronene (empatinevronene) viser blant annet at menneskets evne til empati gjør det mulig for oss å gjenkjenne hverandres følelser og intensjoner (4). 
De fire trinnene i verktøyet tar utgangspunkt i anerkjente psykologiske teorier og forskningsresultater innen narratologi, affektbevissthet, mentalisering og psykoterapi (4).

\section{Unngå at det ender i sykmelding}

Videre, som en del av kollegast $\varnothing t t e n$, tror jeg det også er viktig at det involverte helsepersonellet oppmuntres til å stå frem og informere og forklare pasienten og/eller de pårørende om hva som skjedde, og hvorfor de handlet som de gjorde. Det kan være en god måte å komme seg videre på i sin egen bearbeidingsprosess. I tillegg opprettholder man tilliten til pasienten og/eller de pårørende ved at man tar eierskap til hendelsen.

Uten intern støtte og personlig oppfølging tror jeg veien er kort til sykmelding eller oppsigelse. Negative kommentarer eller syndebukkstempel kan sitte lenge i og er en høy pris å betale for å være sykepleier.

\section{«Uten intern støtte og personlig oppfølging tror jeg veien er kort til sykmelding eller oppsigelse.»}

I alle helseforetak og i kommunehelsetjenesten bør det etter min mening være et oppfølgingsapparat for å forebygge posttraumatisk stresslidelse (PTSD) og i verste fall sekundærtraumatisk stress (STS).

For å få en rask løsning i situasjonen når noen har vært involvert i en hendelse av uheldig karakter, har jeg erfart at kollegaer har blitt anbefalt av lederen å snakke med sin lege om det er best med en sykmelding. Andre har blitt anbefalt å ta ut ferie.

Jeg er usikker på om sykmelding eller ferie er det beste for den ansatte. Vedkommende bør uansett alltid få beskjed om at hendelsen vil bli fulgt opp med samtaler individuelt og i kollegiet. 


\section{Tillit ødelegges når helsepersonell ikke}

\section{tar ansvar}

Som sykepleier kjenner jeg på stor tillit til organisasjoner som har en god og bærekraftig organisasjonskultur når det kommer til kollegast $\varnothing t t e$, åpenhet og ærlighet rundt uønskede hendelser.

En ledelse og et kollegium som ser viktigheten av kollegast $\varnothing t t e$, tror jeg står st $\varnothing$ digere i neste storm. For stormer kommer. Og etter stormene er vi fortsatt avhengig av befolkningens tillit - og tilliten $\varnothing$ delegges ikke av at vi giør feil, men av at vi som helsepersonell ikke tar ansvar.

\section{Referanser}

1. Vangsnes L-E. Når det går galt. Tidsskr Nor Legeforen. 2019:(18). Tilgjengelig fra:

https://tidsskriftet.no/2019/12/fra-redaktoren/nar-detgar-galt (nedlastet 27.08.2021).

2. Mesel T. Når noe går galt. Fortelling om skam, skyld og ansvar i helsetjenesten. Oslo: Cappelen

Damm Akademisk; 2014.

3. Norsk Sykepleierforbund (NSF). Yrkesetiske retningslinjer. Oslo: NSF. Tilgjengelig fra: https://www.nsf.no/sykepleiefaget/yrkesetiskeretningslinjer (nedlastet 27.08.2021).

4. Brudal LH. Empatisk kommunikasjon - et verkt $\varnothing y$ for menneskem $\varnothing$ ter. Oslo: Gyldendal Akademisk; 2014. 